\title{
The Sociocultural Problems of Teaching the Entsy Language
}

\author{
Ksenia V. Reznikova*, Yulia S. Zamaraeva \\ and Natalia A. Sergeeva \\ Siberian Federal University \\ 79 Svobodny, Krasnoyarsk, 660041, Russia
}

In today's world with the pressure of globalization, it is becoming increasing difficult for particular ethnicities to resist assimilation in a large society. The protection of the individual culture from homogenization and standardization is facilitated by maintaining and developing the ethnic language in particular, which is only possible on the basis of high-quality language teaching. Currently, a reduction is not only observed in the Entsys' numbers, but also a drastic reduction in speakers of the Entsy language. This data indicates the presence of problems in education related to teaching the Entsy language. The objective of the article is to identify problems arising in the process of teaching the Entsy language which exist in the sociocultural sphere, and to suggest ways of overcoming them. The main methods used in the present paper include field study, questionnaires, interviews, content analysis. In the course of the study, by way of progressive solution of set tasks, the objective has been achieved: sociocultural problems of teaching the Entsy language have been identified, and solutions have been proposed. The main problems may be listed as follows: a reduction in the Entsys' numbers; a reduction in the number of Entsy language speakers; the absence of an Entsy written language; the focus of the Entsy language and Entsy culture on domestic reindeer amidst almost complete disappearance of reindeer herding among the Entsys; the proclamation of the rights to access preschool and secondary education taught in the Entsy language, while in practice these rights are not exercised. The two main ways to solve the problems identified include the development of the Ensty written language and the revival of reindeer breeding.

Keywords: indigenous peoples, northern territories, entsy, the Enets language, unwritten language, training, reindeer herding.

The reported study was funded by Krasnoyarsk Regional Fund of Science according to the research project: "Development of scientific and methodological support for the preservation of a unique cultural heritage for the Ket and Enets ethno-cultural groups of indigenous small peoples of the North, Siberia and the Far East living on the territory of the Krasnoyarsk Territory".

The reported study was funded by Russian Foundation for Basic Research, Government of Krasnoyarsk Territory, Krasnoyarsk Region Science and Technology Support Fund to the research project No. 17-16-24601.

DOI: 10.17516/1997-1370-0297.

Research area: culturology.

(C) Siberian Federal University. All rights reserved

* Corresponding author E-mail address: axu-ta@mail.ru 


\section{Introduction}

In today's world with the pressure of globalization, it is becoming increasing difficult for particular ethnicities to resist assimilation in a large society. The protection of the individual culture from homogenization and standardization is facilitated by maintaining and developing the ethnic language in particular, which is only possible on the basis of high-quality language teaching. Currently, not only a reduction in the Entsys' numbers is observed (the population is slightly over 200 people), but also a drastic reduction in people Entsy language speakers (from 36 to 45 according to the data from different sources). This data indicates the presence of problems in education related to teaching the Entsy language.

The objective of the article is to identify problems arising in the Entsy language teaching process which exist in the sociocultural sphere, and to suggest ways to overcome them.

The aims of the article include:

- To monitor the sociocultural issues related to teaching the languages of indigenous minority peoples.

- To describe the topical socio-demographic characteristics of the Entsys.

- To reveal the particularities of Entsy language circulation.

- To analyze features of the Entsy language.

- To correlate the right enshrined in legislation for indigenous peoples in linguistic and educational spaces with the real state of affairs in them.

- To provide a clear picture of the sociocultural problems in teaching the Entsy language identified in the study and to suggest ways to overcome them.

A sufficient number of scientific papers are devoted to the preservation of the languages and cultures of the indigenous minority peoples from the North, Siberia, and the Far East. Thus, volumes of research exist on the historiography of scientific research on the indigenous minority peoples of the North residing on the territory of the Russian Federation (Degtyarenko, 2015), on the practices of ethnocultural identity preservation (Kirko, 2015), and on the preservation of the unique northern languages (Bakhtikireeva, 2018).

The Entsy ethnocultural group is concentrated on the contemporary Krasnoyarsk Territory and has a low population. Therefore, a lack of supportive measures to preserve the cultural and linguistic identity and selfidentification of the Entsys may lead to future disappearance of this ethnic group. The proposal of specific solutions to teach the younger and adult population through the Entsy language can emphasize its social significance. Regarding the study of native languages, scientists record a shift in language education in their research, a weakening of the native languages, the need to strengthen their study for the preservation of the unique cultural heritage of the North and to protect linguistic and ethnic diversity in the modern world (Wajda, 2011). In the field of education, the systematic study of native languages is seen as a crucial factor in maintaining ethnic identity (Gashilova, 2015).

Compared with the other North languages, the Entsy language is given very little attention by academia. Linguists mainly identify two dialects (forest and tundra) in the Entsy language, the formal properties of which are diverse in comparison to other world languages. The sociocultural problem in studying the Entsy language is that this is a non-written language, belonging to the Ural Yukaghir language family group (together with the Nganasans, Selkups, and Nenets). However, in the modern Entsy language scientists are discovering a combination of ancestral Ural language structures taken from the Russian language. In his studies of the Entsy language, Shluinsky A.B. traces the similarity 
and compatibility with the Russian language, which enables the bilingual teaching the Entsy language to Russian speakers and/or weaker native language speakers, based on the similarity of the languages.

Several problems are identified, which may be referred to sociocultural. One of them is the lack of professional teacher training in the field of ethnic languages and cultures. Plyusnina E.M., Shalgina E.A., and Shustova S.V. write that there is a need to train experts within the framework of multilingual education, which "contributes to the development and establishment of the personal, intellectual and sociocultural competencies of a future expert to ensure his/her social and occupational mobility when communicating with representatives of other cultures". Multilingual competence allows for the comprehensive study of the native language on equal terms with learning the dominant language (e.g., Russian), and forms an individual's multilingual and sociocultural competence. To develop this competence, the scientists see the need for analysis and careful selection of teaching materials for the language courses, since it affects the comparison of the world view presented in textbooks, and the student's own world view. The concept of studentcentered education comes to the foreground (Shishlova, 2017).

The second problem recorded in modern studies on ethnic linguistics and linguistic cultural studies is the lack of cooperation between the scientific and educational institutions in the field of northern research. The northern languages are studied separately, and are preserved for the most part by academic linguists. For example, for many years based at Tomsk State Pedagogical University the scientists of the Laboratory Department (Department of Siberian Indigenous Languages) have been preserving five endangered northern languages by creating volumes of corpus-based linguistics (using techniques developed by
DoBeS, ELAR, SIL); based on the results of their expeditionary ethno-linguistic research (field expeditions to the places densely populated by the indigenous minority peoples); development and publication of scientific methodical publications. Since 2010, the culturologists at the Siberian Federal University and the scientists from V.P. Astafyev State Pedagogical University have been studying the ethnocultural particularities of the northern peoples (the Evenks, Selkups, Kets, and Chulymms), densely concentrated on the Krasnoyarsk Territory. The joint group of scientists propose possible solutions in creating works of children's literature in the northern peoples' native languages (Koptseva, 2015; Koptseva, 2014).

In the Republic of Sakha (Yakutia), the Digital Humanities project is in place to develop ethnopedagogy, which aims to preserve and promote the languages and cultures of the indigenous minority peoples of the North, Siberia, and the Far East via digital media. Videos and photo shoots of minority native language speakers were taken back from the expeditions, whose speech is recorded on CDs and a public multilingual portal for the indigenous minority peoples of the North has already been created. The aim of the project is to create an information society and attract cultural industries. Based at the North-Eastern Federal University named after M.K. Ammosov, digital technology is used in creating electronic educational resources with the aim of enabling the development of an ethnic identity among indigenous minority children of the North in the learning process, in which the fundamental premise is to study their native language. As for the practical study of the mother tongue, teacher training projects in ethnocultural education competencies run on the University campus. Currently, the projects for developing an information society and the indigenous cultural and educational environment are 
being implemented. However, the sociocultural problem in studying the native language remains the educational environment's inaccessibility in places densely populated by the minority indigenous peoples.

Since 2010, international scientific and practical conferences have been held, dedicated to the preservation and development of the languages and cultures of Siberia's indigenous peoples (St. Petersburg, Moscow, Tomsk, Khakassia). The aim of the scientists' dialog is the identification of priorities for the line of research for language policy, the implementation of innovative work in the area of ethnocultural and bilingual education, the preservation and development of the minority languages and cultures of peoples in Siberia. Scientists acknowledge the need to improve the "effectiveness of teaching native languages, the implementation of research results in the field of languages, and introduce the folklore and literature of the indigenous peoples of Siberia into the practice of modern ethnocultural education". The article "National languages" is devoted to supporting language policy (Tishkov, 2016). The author claims that the death of languages is no more than a myth. Recently, the northern languages have received greater support and recognition than on the territory of the former USSR, no assimilation of these languages with Russian will occur because state policy provides an official status for regional languages as well as "the ethnic component of the federal system in the form of ethnic territorial and nationalcultural autonomy for certain regions and ethnic communities". Koptseva N.P. and Kirko V.I. in the article "Ethnic identification of indigenous people of the Siberian Arctic" note that a reduced capacity to maintain one's own culture may occur in the territories of the indigenous peoples of the North in the Krasnoyarsk Territory in connection with the new industrialization. Therefore, it is necessary to adopt urgent regulations (laws) to protect the rights of indigenous peoples for the preservation of the language for its fluent use in everyday communication (Koptseva, 2017).

In her long-term studies of the Evenk language, Bulatova N.Ya. also sees a resurgent interest not only in the national languages, but also in many languages of the minority peoples of the North, Siberia, and the Far East. According to the scientist, the sociocultural problem lies in the lack of school textbooks in local dialects, the prevailing discrepancy between them, which leads to problems with language communication. Without 'live' study of the mother tongue, which is effectively preserved in the dialogs of preschool and school education, the sociocultural problem of teaching native languages becomes apparent. A possible solution to develop the mother tongue will be attracting the native speakers themselves, who communicate in their native language in everyday life with their relatives, and educators who will be able to preserve the content of the unique language in the new state educational standards (Bulatova, 2017a). Another way to preserve the language is to create thematic dictionaries in two and/or three languages (for example, Evenk-Russian-English, Teleut-Russian-English) with two forms of consumption (print and electronic). The authors believe that shifting the lexical units to electronic sound will promote motivation and maintain the youth's interest in studying the native language (Bulatova, 2017b).

Some scientific research focuses on the topic of education and studying among children of northern peoples. Thus, Koptseva N.P., Reznikova K.V., Pimenova N.N., Kistova A.V. note that the culture of childhood is at its most vulnerable in the processes of global changes in the twenty-first century. It is the younger generation that can be motivated to preserve their unique culture. The sociocultural aspect is at risk, as in the near future the traditional culture of childhood among the 
indigenous peoples of the Krasnoyarsk Territory "will only be in the form of virtual information or will disappear along with the native languages of cultural groups" (Reznikova, 2016; Reznikova, 2015).

One of the solutions to support the study of the Entsy language could be the implementation of modern innovative technology that contribute to the preservation of the unique cultural phenomena of this ethnocultural group (Kopyova, 2017).

According to scientists, another way to save endangered languages of the minority indigenous peoples of the Russian North is the idea of "a language nest", which facilitates immersion in the language environment during education. Only using the ethnic language provides the speaker with a powerful impetus to study and ensures the effective assimilation of the ethnic language as a mother tongue (Koptseva, 2014). Language skills provide an opportunity for the development of communicative and cultural competence, an individual's socialization (both child and adult) in an environment. The sociocultural problem of studying ethnic language can be solved by including forms of visual communication in the educational process: by comparing the imagery of languages (cartoon visualization of northern fairytales, myths, legends), immersion in an authentic language and cultural environment (the "language nest" method), analysis of difficulties encountered in the process of studying the ethnic language as a mother tongue, encouraging the younger generation to create modern texts, poems on the northern themes.

\section{Materials and Methods}

The main methods used in the present paper include field study, questionnaires, interviews, content analysis. Particular attention should be paid to the field study in the northern regions of the Krasnoyarsk Territory in progress since 2010.
During this period, participant observation has been carried out in the indigenous regions of the Selkups, Evenks, Nenets, Dolgans, Yessey Yakuts and other indigenous peoples of the North.

\section{Results}

\section{Sociocultural problems related to teaching} the languages of indigenous minority peoples.

Field research carried out in the northern areas of the Krasnoyarsk Territory has allowed us to define the range of problems existing in the sphere of children's ethnic language study. On the one end of the range are the endangered languages; on the other are the ethnic languages overriding Russian despite the relative low population of their speakers, which leads the speakers' problems in their adaptation to "larger" Russian society.

Selkup may be taken as the first example of a language from the endangered languages group. If the parents of most modern middleaged Selkups communicated fluently in their native language, spoke it at home and at the fisheries, then the middle-aged Selkups can be divided into three groups: some often know only some words; others know the language, but they do not use it in practice and speak only Russian; the third group as a rule are people engaged in traditional crafts, they are not only fluent in their native language, but also use it actively. Part of the younger generation knows words from the Selkup language, are familiar with the principles of its construction because it is taught at school, but teaching has failed to return the language to the children's lives and the adolescent environment, they never actually use it (except those who are actively engaged in traditional crafts with parents). The Selkups complain that schools do not teach their children the local dialect of Selkup: according to the residents of Farkovo (a densely populated Selkup settlement in the Krasnoyarsk Territory), there exist three dialects of their ethnic language: Turukhansk, 
Taz, and Baishin; at school they teach not the local Turukhansk dialect, but the Taz one, i.e. the dialect of the Selkups residing along the Taz river in other regions of Siberia. Thus, many adults do not want their children to learn Selkup at school.

Teaching the Nenets language is faced with other difficulties. Many Nenets lead a nomadic lifestyle, children of people residing in the Tundra are brought to a boarding school at the age of 6.5-7 years, part of them do not go to the first class and attend zero class, where they are taught the Russian language, as while living with parents in the Tundra, they are accustomed to only communicating in the ethnic language. Head teachers say that almost $90 \%$ of pre-school children do not speak Russian. In addition to Russian and English, the Nenets children are taught the Nenets language at school. The educators here also note one more problem, which is that the Nenets language was artificially systematized during the Soviet time: several dialects of Nenets existed and continue to exist, which were standardized by scientists as one language variant, the scientists introduced the written form of the language as well, originally absent among the Nenets. Additionally, children who had mastered conversational Nenets in natural circumstances experience difficulties in grasping the adapted artificial language.

Topical socio-demographic characteristics of the Entsys. The Entsys reside mainly in the territory of the Taymyrsky Municipal District in the Krasnoyarsk Territory. Typically, researchers involved in studying the Entsy culture argue that there is an extremely small number of Entsys left, that they are on the verge of complete assimilation. The 1989 census registered about 100 Entsys; 2010 census recorded 227 Entsys. Changes in number are related not only to demographic processes, but also to ethnic identity and selfidentity: a person may change his/her ideas about their ethnic identity several times in their life, as well as being put down as belonging to one or another nation by outside institutions. Being peoples of extremely low population, the Entsys are endangered as an ethnic group due to a high number of mixed marriages.

This does not facilitate the preservation of the Entsys and the particularities of their settlement: the representatives of the peoples live in fairly dense "Entsys" settlements (Vorontsovo and Potapovo); in 1992, they collectively had a population of $72.8 \%$ of all Entsys, while in 2002, there were $57.9 \%$. However, these figures need to be considered in the ratio of Entsys to representatives of other ethnic groups living in these settlements. Thus, as of 2002, there were 43 Entsys in Vorontsovo, representing only $12.4 \%$ of the settlement's population; for comparison: there were 219 Nenets in Vorontsovo in the same year, or $63.3 \%$ of the population. In Potapovo in 2002, there were 99 Entsys, or $23.8 \%$ of the population; Russians amounted to 106 people, or $25.5 \%$ of the population. In addition, the polyethnicity of the "Entsys" settlements should be noted: each of them is also home to Nenets, Russians, Dolgans, Ukrainians, Germans, Tatars, Uzbeks, Belarussians, Finns, Chuvashes, etc.

\section{Particularities of Entsy language} prevalence. The Entsy language belongs to the Uralic language family, to its Samoyedic branch. The forest and tundra dialects are distinguished within the Entsy language. For the last 15 years (from 2002 to 2017) the number of the Entsy language speakers fell to almost half (from 83 to 45 people). In addition, the following important aspects have been identified: firstly, less than half of the Entsys under the age of 40 consider the Entsy language a mother tongue. Moreover, in the age groups of under 30 , less than $10 \%$ of people recognize the Entsy language a mother tongue. Secondly, the age of 40 (referring to data from 2002) is a critical point: in the group of Entsys over 40 , there are more people who describe 
Entsy as their mother tongue and not Russian (the ratio varies from 100:0 to 73:25); in the group of Entsys under 40 the opposite applies (the ratio is from 39:58.4 to 0:100). In 2002, people born in 1962 turned 40.

Thirdly, at the age of 10 no Entsys consider the Entsy language their mother tongue, albeit one of the two native $3.8 \%$ of Entsys under the age of 10 consider Russian and Nenets their native languages). Fourthly, another turning point can be pinpointed in the ratio of Entsy and Nenets languages as native languages for the Entsys: in the group of Entsys over 30, there are more people who describe Entsy as their mother tongue as opposed to Nenets (the ratio varies from 100:0 to 39:11.1); in the group of Entsys under 30 the opposite applies (the ratio is from 6.5:19.5 to 0:3.8). In 2002, people born in 1972 turned 30. As of 2002, no Entsys under 20 speak the Entsy language fluently, or at best experience some difficulties; the younger the Entsys, the poorer their fluency in Entsy is. The reduction in indicators related to fluency in Entsy, as well as in its recognition by the Entsys as their mother tongue is additionally related to the absence of a written Entsy language.

\section{The particularities of the Entsy language.} Entsy is not a written language. Its sounds can be transcribed using the Cyrillic alphabet supplemented by three additional characters:

- guttural consonant sound close to nasal [n];

- coarsened front mid vowel sound close to [Ә];

- glottal stop sound.

Further features of the Entsy language will be studied based on analysis of the thematic section of the "Entsy Picture Dictionary" by Z.N. Bolina (2012). This dictionary is aimed at children of pre-school and primary school age, therefore, it contains the most important, fundamental terms for a language. The primary analysis of the dictionary allows us to make several conclusions: firstly, deer are of the greatest importance for the
Entsys: the children's dictionary contains such deer-related topics as "Varieties of deer fur" (11 items); "Names of the reindeer in harness" (10); "Deer" (22); "Harness" (5). Specific items are present in other sections, including the mention of deer, for example the "Definition of person by occupation" (6 of 18 items are related to deer, for example "tenyda: driver of deer herds", "marituda enchi: a person who rides in the tundra to find lost deer", etc.); "Tools for men's work" ("Chezy-maut: a long rope made of rovduga (deer hide) for catching deer", etc.). For comparison, the section "Wild animals" includes a total of 16 items, "Domestic animals" contains 6 items; 2 of the six are actually deer (te) and a deer herding dog (te ponida bunyk). Secondly, the list of domestic animals (6 items) is shorter than that of wild animals (16), insects (16), birds (21), fish (12); it follows that the Entsy culture is mainly dependent on the external environment, while the internal one is almost entirely focused on deer. Thirdly, the Entsy culture tends to differentiate what is male and female, which is defined in various spheres: these are clothes, tools of work, a variety of sleds.

Let's analyze the concept of "deer" in the Entsys language in detail. The term "deer" is presented in the following sections of the dictionary: men's clothing (2 items of 15); hunting equipment ( 1 of 24); tools for men's work (1 of 19); parts of the sled (2 of 10); women's clothing (4 of 14); tools for women's work (2 of 13); food (4 of 38); months (3 of 12); insects (1 of 16); domestic animals ( 2 of 6 ); definition of a person by occupation (6 of 18). It should be specified that the representation of the term "deer" was only considered in cases where the deer was referred to. That is, the following was considered as a unit, for example "koba pagi: parka made of deer fur", but the word was not included in: "tobak-fur stockings (fur inside)", as they can be produced both from deer fur and 
the fur of other animals, etc. The dictionary also contains sections completely devoted to deer or directly associated with them, these are sleds (5 items); harness (5); names of the deer in harness (10); varieties of deer fur (11); deer (22).

Let's continue analysis on the basis of definitions of Entsy words related to deer, in which aspects of human life they are most important; what criteria classify the deer.

Reindeer herding as the main type of economic activity. The section "Definition of a person by occupation" (total 18 items) contains the following Entsy occupations: reindeer breeding (6), training/education (4); men's trades (3), women's trades (2), work in the chum (rawhide tent) (1).

Reindeer breeding is rather sophisticated with distinguished occupations: "te ponida: a deer breeder"; "tenyda: a deer herd driver"; "ezzuda: a person who rides a reindeer sleigh"; "marituda enchi: a person who rides in the tundra to find lost deer"; "tedaguza: a herder who grazes deer during the day"; "beza: a herder who guards deer at night".

A detailed classification of types of domestic deer is also given, based on the following features:

- sex (castrate bull, stag, doe, doe in fawn, non-pregnant doe, young doe, one-year-old doe, two-year-old doe, two-year-old stag);

- age (newborn deer, fawn, young doe, oneyear-old doe, two-year-old doe, two-year-old stag);

- reproductive features (castrate stag, calfbearing doe, non-pregnant doe);

- domestication degree (unbacked deer, docile deer, deer domesticated to eat from the hand, wild, domestic, trained to work harnessing in a sleigh);

- fur color, on the one hand allows the easy identification of deer in the herd, on the other, is variously valued for the manufacture of clothing, shoes and household items (silver-colored fur, red, speckled, white).
Deer as a means of transport. Deer vary depending on the position in a sleigh harness (leader, by the leader, in the middle, rear, by the rear); the verbs defining sleigh movement vary with the number of deer (sledding with two, three, four, five, six deer); men's occupation is often associated with the movement in a sleigh (the man who rides a sleigh; a man who rides in the tundra to find lost deer, etc.), etc.

Deer as a source of material: fur and leather. Kamus is the material used to sew men's and women's winter shoes; rovduga is for summer; fur is used to sew a women's parka; rovduga is used to make ropes; skins are used during argishes (trips) on deer sleighs. Deer fur and skin are valuable. The importance of deer as a source of material is emphasized by the wide range of fur variety names depending on the following factors:

- the age of a deer (newborn, one month old fawn, autumn calf);

- the time of year when the deer fur was taken (August fur, winter, autumn, summer fur);

- the part of the deer's body the fur was taken from (muzzle, legs, whole body, feet).

Moreover, different kinds of fur determine the equipment used in women's crafts: for finishing fur, kamus, rovduga.

Deer as a food source. The Entsys use reindeer meat, fat and milk and consume them in various forms: raw, dried, boiled, stewed.

Deer as the basis of understanding the annual cycle: the Entsys have three of twelve months names related to deer: "nezy diri - May ("month of fawns")"; "kora diri-October ("month of the stag of domestic deer")"; "kezar kora deriNovember ("month of the stag of wild deer")". The names of three more months in the Entsy language are associated with animals: April - the month of the eagle (arrival of the eagles), July the month of the mosquito (the greatest activity of mosquitoes), August - the month of geese (hunting 
season); four names of months are connected with natural phenomena: February is the cold month, June is the month of water, September is the month without leaves, December is the month of great darkness; two names of months are connected with seasonal work: January is the month of the axe handle, March is the month of long trips. In fact, it is possible to classify four names of months as deer-related since long trips (March) are carried out on deer.

Deer as the basis for the relationship with the animal world. In the Entsy language, among all dogs ("bunyk") deer herding dogs ("te ponida bunyk") are distinguished; among the gadflies ("pilyu") - their maggots found under the skin of a deer ("shui").

Having uncovered such a meaningful and even fundamental role in the "deer" concept for the Entsy language, we should refer to data concerning the current status of reindeer breeding. Thus, in 2002 only 16.4\% of Entsy men were engaged into reindeer breeding, $36.6 \%$ of Entsy men referred to reindeer breeding as their primary occupation.

Legislation on the languages of the indigenous minority peoples of the Krasnoyarsk Territory. According to the law of the Krasnoyarsk Territory from November 05, 2015 No. 9-3816 “On the native (national) languages of the indigenous minority peoples residing in areas of the Krasnoyarsk Territory", the mother tongues of minority peoples (including the Entsy - cl. 1.1) inter alia include "the most important element of the ethnic culture of minority peoples" (cl. 1.1). Pursuant to Law No. 9-3816, in places where indigenous minority peoples are traditionally resident and places of their traditional economy, a native language can be used along with the state language in official spheres of communication (cl. 2.2); it can be used in mass media broadcasts (cl. 7.1); native languages can be used for official names geographical objects, signs, inscriptions (cl. 8).
Article 9 "The right to choose the language of education and study" is of a particular interest, cl. 1 of which reads as follows: "Individuals belonging to minority peoples are entitled to receive pre-school, general primary and basic education in the mother tongue, as well as the right to study their native language within the opportunities offered by the educational system, in the order established by the legislation on education". In the case of the Entsy language, this means that the Entsys are entitled to recieve school education in the Entsy language, but they cannot exercise this right due to the lack of opportunities to be taught in this language.

The identified sociocultural problems in teaching the Entsy language and their solutions. The completed research enables the following conclusions to be made:

A decline in the Entsys' numbers has been observed due to natural demographic processes (mortality), miscegenation, and changes in ethnic identity. No truly "Entsy" settlements exist: in those deemed as such, polyethnic villages Vorontsovo and Potapovo, the proportion of the Entsy population does not exceed $24 \%$. It is worth noting that in Vorontsovo the dominant ethnic group is the Nenets (over 60\%), in Potapovo, Russians make up the highest proportion in the population (over $25 \%$ ).

According to 2017 data, a reduction in the number of Entsy language speakers has been observed: there were no more than 50 Entsys (belonging exclusively to the age group of over 45), speaking the mother tongue with varying degrees of fluency. According to 2002 data, less than half of Entsys under 40 (born in 1962 and later) considered the Entsy language their mother tongue, the Russian language is most often listed in this age group. According to 2002 data, there are more Entsys under 30 (born in 1972 and later) who consider the Nenets language as their mother tongue rather than Entsy. The disappearance of the Entsy language 
is related to the absence of a written language, however, the Entsys themselves are divided in their attitude towards the idea of its creation.

Familiarization with the thematic section of the Entsy language dictionary (the forest dialect) has revealed the Entsys culture's focus on domestic deer, as well as the importance of differentiation between male and female (it concerns clothing, sleds, activities, etc.).

The study allowed us to identify the fundamental role of the "deer" concept in the Entsy language. Deer breeding is represented in the Entsy language as the main kind of economic activity, the deer is viewed as a means of transport, as the source of material (fur and leather), as nourishment, as a basis for understanding the annual cycle, as the basis for the relationship with the animal world.

In 2002 , only $16.4 \%$ of Entsys were occupied in deer breeding, although $36.6 \%$ of them named this work as their primary occupation. Thus, it may be said that there is a continuing decline in the number of Entsys engaged in deer breeding, which is only preserved in the Tukhardskaya tundra where the Entsys are becoming absorbed by the Nenets.

Regional legislation provides the right not only to use the Entsy language (as well as any other language of indigenous minority peoples) in the territories of their original residence for communication in official spheres, for mass media broadcasting, etc., but also the right to receive pre-school and secondary education in the Entsy language. These rights are not exercised in practice.

Based on the presented findings, firstly it is possible to forecast the impending disappearance of the Entsy language, as well as a drastic reduction in the number of Entsys in general and the number of proficient Entsy language speakers (as their aging also takes place), and the reduction and aging of the Entsys who consider the Entsy language their native one, rather than Russian or Nenets.

Secondly, it can be assumed that since the concept of "deer" is fundamental to the Entsy language, the revival of the Entsy language is almost impossible without revival of the deer breeding. The strong interconnection between deer breeding, the ethnic group and the language can explain why young Entsys' (born after 1972) consider their native language not only Russian, but also Nenets (the Nenets, unlike the Entsys, continue to practise deer breeding).

\section{Conclusion}

In the course of the study, by way of progressive solution of set tasks, the objective has been achieved: sociocultural problems of teaching the Entsy language have been identified, and solutions have been proposed. The main problems may be listed as follows: a reduction in the Entsys' numbers; a reduction in the number of Entsy language speakers; the absence of an Entsy written language; the focus of the Entsy language and Entsy culture on domestic reindeer amidst almost complete disappearance of reindeer herding among the Entsys; the proclamation of the rights to access pre-school and secondary education taught in the Entsy language, while in practice these rights are not exercised. The two main ways to solve the problems identified are firstly, the development of the Ensty written language, and secondly, the revival of reindeer breeding.

\section{References}

Bakhtikireeva, U.M., Dzhusupov, M., Saparova, K.O. (2018). Kontaktirovaniye yazykov i kul'tur: sovershenstvovaniye, ischeznoveniye. Stat'ya-retsenziya na kollektivnuyu monografiyu «Yazykovaya kartina mira teleutov» [Contacting languages and cultures: improving, disappearing. Article-review of the collective monograph "Language Picture of the World of Teleuts"]. In Filologicheskiye nauki. 
Nauchnyye doklady vysshey shkoly [Philological Sciences. Scientific reports of the higher school], 1, 112-120. DOI: 10.20339 / PhS.1-18.112

Bulatova, N.Ya. (2017). Yazykovyye protsessy v epokhu obshchestvennykh transformatsiy (na materiale evenkiyskogo yazyka) [Language processes in the era of social transformations (based on the Evenk language)]. In Teoreticheskaya i prikladnaya lingvistika [Theoretical and applied linguistics], 3(2), 5-19. DOI: 10.22250 / 2410-7190_2017_3_2_5_19

Bulatova, N.Ya., Morozova, O.N. (2017). Zadachi i printsipy sostavleniya zvukovogo evenkiyskorussko-angliyskogo tematicheskogo slovarya [Tasks and principles of composing the sound EvenkRussian-English thematic dictionary]. In Teoreticheskaya i prikladnaya lingvistika [Theoretical and applied linguistics], 3(4), 5-12. DOI: 10.22250 / 2410-7190_2017_3_4_5_12

Bystryakov, A.A. (2017). Teoreticheskiye osnovaniya psikhologo-pedagogicheskoy adaptatsii pervoklassnikov s zaderzhkoy psikhicheskogo razvitiya - predstaviteley korennykh malochislennykh narodov severa [Theoretical bases of psychological and pedagogical adaptation of first-graders with mental retardation - representatives of indigenous peoples of the North]. In Nauchno-metodicheskiy elektronnyy zhurnal Kontsept [Scientific and methodical electronic journal "Contsept"], 12, 59-63. DOI 10.24422/MCITO.2017.12.8659/

Degtyarenko, K.A. (2015) Aktual'noye sostoyaniye korennykh malochislennykh narodov severa [Actual state of indigenous small-numbered peoples of the North]. In Sotsiodinamika [Sociodynamics], 10, 39-57. DOI: 10.7256 / 2409-7144.2015.10.16435

Galtseva, N.V., Favstritskaya, O.S., Sharypova, O.A. (2017). Uroven' zhizni naseleniya severnykh i arkticheskikh territoriy Dal'nego Vostoka Rossii [The standard of living of the population of the Northern and Arctic areas of the Russian Far East]. In Regional'naya ekonomika: teoriya i praktika [Regional Economy: Theory and Practice], 1, 85-100. DOI: 10.24891/re.15.1.85

Gashilova, L. (2015). Obrazovanie kak faktor sokhraneniya yazykov i kul'tur korennykh narodov severa [Education as a factor of preservation of languages and cultures of northen indigenous peoples]. In Arkticheskij dialog v global'nom mire. Materialy nauchno-obrazovatel'noy konferentsii [Arctic dialogue in the global world. The Proceedings of Joint Science and Education Conference], 260-261. DOI: 10.18101 / 978-5-9793-0754-1-260-261

Kirko, V.I. (2015). Postsovetskiye praktiki sokhraneniya etnokul'turnoy identichnosti korennykh narodov severa i Sibiri v Krasnoyarskom kraye Rossiyskoy Federatsii [Post-Soviet practices of preserving the ethno-cultural identity of the indigenous peoples of the North and Siberia in the Krasnoyarsk Territory of the Russian Federation]. In Sotsiodinamika [Sociodynamics], 6, 113-133. DOI: 10.7256 / 2409-7144.2015.6.15607

Koptseva, N.P., Kirko, V.I., Nevzorov, V.N., Razumovskaya, V.A., Semenova, A.R., Bukharova, E.B., (2016). Traditional nature management areas as means of organizing the economic activities of the Siberian arctic's indigenous minorities. In International Review of Management and Marketing, 6(5s), 154-161.

Koptseva, N.P., Kirko, V.I. (2015). The Impact of Global Transformations on the Processes of Regional and Ethnic Identity of Indigenous Peoples Siberian Arctic. Mediterranean Journal of Social Sciences, 6(3 S5), 154-161. DOI: 10.5901/mjss.2015.v6n3s5p217

Koptseva, N.P., Kirko, V.I. (2014). Ethic identification of indigenous people of the Siberian Arctic. In American Journal of Applied Sciences, 11(9), 1573-1577. DOI: 10.3844/ajassp.2014.1573.1577

$$
-1147-
$$


Koptseva, N.P., Krupkina, K.A., Kirko, V.I. (2017). Ethnic identity intercity among the chulyms, selkups, kets, and evenks: the indigenous peoples of Eastern Siberia. In SGEM International Multidisciplinary Scientific Conference on Social sciences and Arts, 6(2), 685-692. DOI: 10.5593/ sgemsocial2017/62/S28.084

Kopyova, D.A, Androsova, S.V. (2017). "Yazykovoye gnezdo" kak sposob resheniya problemy sokhraneniya evenkiyskogo yazyka v Amurskoy oblasti ["The language nest" as a way to solve the problem of preserving the Evenki language in the Amur region]. In Teoreticheskaya i prikladnaya lingvistika [Theoretical and applied linguistics], 3(3), 17-25. DOI: 10.22250/2410-7190_2017_3_3_17_25

Leonov, S.N., Shevareva, Ya.S. (2017). Problemy i perspektivy razvitiya traditsionnykh vidov khozyaystvennoy deyatel'nosti korennykh malochislennykh narodov severa Dal'nego Vostoka [Problems and Prospects of Development of Traditional Economic Activities of Indigenous People of Russian Far Eastern North]. In Regionalistica [Regionalistics], 2, 26-45. DOI: 10.14530/reg.2017.2.

Novachuk, P.A. (2017). Formirovaniye etnokul'turnoy kompetentnosti detey doshkol'nogo vozrasta sredstvami fol'klora [Formation of ethnocultural competence of children of preschool age by means of folklore]. In Nauchno-metodicheskiy elektronnyy zhurnal Kontsept [Scientific and methodical electronic journal "Contsept”], 12, 42-51. DOI 10.24422/MCITO.2017.12.8657

Plyusnina, E.M., Shalgina, E.A., Shustova, S.V. (2017). Formirovaniye mul'tilingval'noy kompetentsii [Formation of multilingual competence]. In Vestnik Permskogo natsional'nogo issledovatel'skogo politekhnicheskogo universiteta. Problemy yazykoznaniya i pedagogiki [Bulletin of the Perm National Research Polytechnic University. Problems of linguistics and pedagogy], 2, 121130. DOI: 10.15593 / 2224-9389 / 2017.2.12

Reznikova, K.V., Koptseva, N.P., Seredkina, N.N., Zamaraeva, Y.S. (2016). Regional specifics of social values and their impact on Central Siberian territories' modernization (based on research of Krasnoyarsk region). In Economic Annals, 160 (7-8), 92-95. DOI: 10.21003/ea.V160-18

Reznikova, K.V., Zamaraeva, J.S., Kistova, A.V., Pimenova, N.N., Seredkina, N.N. (2015). Taymyr Reindeer Herding as a Branch of the Economy and a Fundamental Social Identification Practice for Indigenous Peoples of the Siberian Arctic. In Mediterranean Journal of Social Science, 6(3), 225-232. DOI: 10.5901/mjss.2015.v6n3s5p225

Shishlova, E.Ye., Kuritsyn, I.A. (2017). Skrytoye soderzhaniye professional'nogo yazykovogo obrazovaniya v sotsiokul'turnom izmerenii [Hidden Content of Professional Language Education in the Sociocultural Dimension]. In Integratsiya obrazovaniya [Integration of Education], 21(4), 709722. DOI: 10.15507 / 1991-9468.089.021.201704.709-722.

Tomaska, A.G. (2014). Sotsial'naya adaptatsiya uchashcheysya molodezhi korennykh malochislennykh narodov severa $\mathrm{v}$ gorodskikh usloviyakh [Social adaptation of pupils of indigenous peoples of the North in urban conditions]. In Sovremennyye issledovaniya sotsial'nykh problem [Modern Research of Social Problems], 8, 174-186. DOI: 10.12731/2218-7405-2014-8-16

Tishkov, V.A. (2016). Yazyki natsii [Languages of the Nation]. In Vestnik Rossiyskoy Akademii Nauk [Bulletin of the Russian Academy of Sciences], 86(4), 291. DOI: 10.7868 / S0869587316040174

Utemov, V.V., Gorev, P.M. (2018). Mezhpredmetnaya tekhnologiya adaptivnogo obucheniya i testirovaniya $\mathrm{v}$ shkol'nom obrazovanii [Interdisciplinary technology of adaptive learning and testing in school education]. In Nauchno-metodicheskiy elektronnyy zhurnal Kontsept [Scientific and methodical electronic journal “Contsept”], 3, 1-11. DOI 10.24422/MCITO.2018.3.11503. 
Utemov, V.V., Gorev, P.M. (2018). Tekhnologiya razrabotki korobochnykh obrazovatel'nykh resheniy [Technology of box educational solutions development]. In Nauchno-metodicheskiy elektronnyy zhurnal Kontsept [Scientific and methodical electronic journal "Contsept”], 1, 22-31. DOI 10.24422/MCITO.2018.1.9687

Wajda, E. (2011). New perspectives in language assessment: the interpretivist revolution. In Second Language Learning and Teaching, 1, 275-285. DOI: 10.1007/978-3-642-20141-7_21

\title{
Социокультурные проблемы обучения энецкому языку
}

\author{
К.В. Резникова, Ю.С. Замараева, \\ Н.А. Сергеева \\ Сибирский федеральный университет \\ Россия, 660041, Красноярск, пр. Свободный, 79
}

В современном мире под натиском глобализации отдельным этносам становится все сложнее сопротивляться растворению в большом обществе. Защите собственной культуры от гомогенизаџии и унификации способствуют поддержание и развитие родного языка, которые возможны лишь на базе качественного обучения. В настоящее время наблюдается не только сокращение количества энщев, но также и резкое сокращение людей, владеющих энецким языком. В образовательной сфере существует ряд проблем, связанных с обучением энечкому языку. Цель статьи - выявить проблемы в процессе обучения энеикому языку, существуюшие в социокультурной сфере, и предложить пути их преодоления. В качестве основных методов, использованных в настоящей работе, можно назвать полевое исследование, анкетирование, интервьюирование, контент-анализ. В ходе проведенного исследования путем постепенного решения поставленных задач достигнута цель - выявлены социокультурные проблемы обучения энецкому языку и предложены пути их преодоления. Основные проблемы: сокращение числа энщев; сокращение числа говорящих на энецком языке; отсутствие энецсой письменности; фокусирование энеикого языка и энеикой культуры на домашнем олене в условиях практически полного исчезновения северного домашнего оленеводства среди энщев; декларация права использования энеикого как языка получения дошкольного и среднего образования, на практике эти права не реализуются. В качестве двух основных путей преодоления данных проблем могут быть названы разработка энеикой письменности и восстановление северного домашнего оленеводства.

Ключевые слова: коренные народы, северные территории, энщъы, энецкий язык, бесписьменный язык, обучение, оленеводство.

Исследование выполнено при поддержке Красноярского краевого фонда науки в рамках реализачии проекта: «Разработка научно-методического обеспечения сохранения уникального культурного наследия для кетской и энецкой этнокультурных групп коренных малочисленных народов Севера, Сибири и Дальнего Востока, проживающих на территории Красноярского края».

Исследование выполнено при финансовой поддержке Российского фонда фундаментальных исследований, Правительства Красноярского края, Красноярского краевого фонда поддержки научной и научно-технической деятельности в рамках научного проекта № 17-16-24601.

Научная специальность: 24.00.00 - культурология. 
